\title{
KARAKTERISTIK TERMAL PADA UMA LENGGE DI DESA MBAWA NUSA TENGGARA BARAT
}

\author{
SUWANTARA, I Ketut ${ }^{1}$, DAMAYANTI, Desak Putu ${ }^{2}$ dan SUPRIJANTO, Iwan ${ }^{3}$ \\ 1,2 B. PTPT Denpasar, Email: tara_iwan@yahoo.com; dama_balai@yahoo.com \\ ${ }^{3}$ Balai PTPT Denpasar B. PTPT Denpasar, Email: iwan_suprijanto@ rocketmail.com
}

\begin{abstract}
ABSTRAK
Kearifan lokal rumah tradisional Uma Lengge merupakan pengetahuan yang dikembangkan oleh masyarakat setempat, yang didapatkan melalui proses trial \& error sebagai proses untuk dapat beradaptasi dengan lingkungan fisiknya. Terletak di Desa Mbawa, Propinsi NTB, bangunan tersebut terbukti mampu beradaptasi dengan iklim tropis lembab lembab ddengan suhu rata-rata harian $25^{\circ} \mathrm{C}$. Namun, potensi tersebut tidak sejalan dengan fakta di lapangan yang justru menunjukkan bahwa rumah tradisional Uma Lengge mulai berkurang keberadaannya. Hal ini menjadi permasalahan tersendiri, dimana kajian yang ada, cenderung mengangkat sebatas karakteristik fisik bangunan dan belum menyentuh mengenai kajian ilmiah dari segi science bangunan. Tulisan ini akan mengkaji mengenai karakteristik termal Uma Lengge sebagai masukan ilmiah tentang potensi kearifan lokal di dalamnya. Pengukuran terfokus pada paramater iklim (suhu, kelembaban, dan kecepatan angin) selama 24 jam pada musim hujan dan kemarau. Diperoleh hasil bahwa Uma Lengge mampu menghangatkan ruangan $0,1^{\circ} \mathrm{C}$ pada musim hujan dan lebih rendah $0,8^{\circ} \mathrm{C}$ pada musim kemarau dibandingkan suhu luar ruangan. Hal ini merupakan potensi tersembunyi yang patut untuk terus terlestarikan.
\end{abstract}

Kata kunci: Tradisional, uma lengge, karakteristik termal.

\begin{abstract}
Local wisdom of Uma Lengge traditional houses were really knowledge developed by local people, obtained through a process of trial \& error, as the process to be able adapt the physical environment. Located in Mbawa village, west nusa tenggara province, the building has proven to be able of adapting to the humid tropical climate with an average daily temperature $25^{\circ} \mathrm{C}$. However, that potential was not consistent in the field facts that shows the Uma Lengge traditional houses waning existence. This is a separate issue, assessments, tend to raise the extent of the physical characteristics building and has not been touched in terms of scientific study of science building. This paper will examine the Uma Lengge thermal characteristics as scientific input on potential local wisdom. Measurements focused on climate parameters (temperature, humidity, and velocity) for 24 hours in the wet and dry season. The results show that Uma Lengge able to warm the $0.1^{\circ} \mathrm{C}$ in the wet season and able to refrigerate $0.8{ }^{\circ} \mathrm{C}$ in the dry season compared with outdoor temperature. This is a hidden potential that ought to be kept preserved.
\end{abstract}

Keywords: Traditional, uma lengge, thermal characteristic

\section{PENDAHULUAN}

Rumah tradisional umumnya dibangun tanpa didukung oleh teori atau prinsip bangunan, menyesuaikan dengan iklim dan lingkungannya, dibangun secara bersama-sama dan menyesuaikan dengan kemampuan masyarakatnya (ekonomi dan teknologi), serta memanfaatkan material alam (Rapoport, 1969). Hingga saat ini telah banyak riset-riset yang dilakukan terkait obyek rumah tradisional di nusantara, namun, sebagian besar hanya terfokus pada identifikasi dan transformasi rumah, sedangkan kajian ilmiah yang terkait dengan sains bangunan masih termarjinalkan (Sueca, 1997).

Kajian rumah tradisional dari segi termal bangunan terhadap adaptasi lingkungan fisiknya patut dijadikan pertimbangan ilmiah yang menarik sebagai pembelajaran desain ke depannya. Unsur-unsur ruang, bahan, dan bukaan pada rumah tradisional diciptakan untuk dapat beradaptasi dengan kondisi iklim setempat. Kondisi iklim tropis lembab di Indonesia yang memiliki 2 (dua) ? musim menuntut desain bangunan yang mampu menghangatkan suhu ruang di musim hujan, tetapi juga mampu mendinginkan suhu ruang di musim kemarau sehingga menciptakan kondisi termal bangunan yang nyaman untuk ditinggali.

Arsitektur Sasak di Provinsi Nusa Tenggara Barat, sebagai salah satu ragam arsitektur Nusantara, masih dapat ditemukan di Desa Mbawa, khususnya pada terlihat pada fasade Uma Lengge. Uma Lengge menjadi contoh khas bangunan yang terbukti mampu 
menyesuaikan dengan iklim setempat. Studi ini berupaya mengevaluasi bangunan Uma Lengge dalam batasan kriteria fisika bangunan, khususnya yang terkait dengan kenyamanan termal. Diawali dengan kajian karakteristik dasar Uma Lengge, pengukuran iklim, diikuti oleh pemeriksaan unsur-unsur fisik seperti panas, kelembaban, kecepatan angin, dan radiasi matahari.

\section{METODE PENELITIAN}

Penelitian ini dilakukan berdasarkan hasil observasi lapangan dengan batasan kajian pada kenyamanan termal statis pada musim hujan (Maret, 2011) dan kemarau (Juli, 2011). Pengukuran yang dilakukan selama 1 x 24 jam pada rumah tradisional Uma Lengge di Desa Mbawa, NTT. Suhu dalam dan luar ruangan yang menjadi fokus pengukuran, diukur secara bersamaan dengan rentang waktu pengukurannya adalah 1 jam. Suhu udara kering $\left(T_{d b}\right)$, suhu permukaan bahan baik bagian dalam dan luar diukur dengan alat Logger (Gambar 1). Logger merekam suhu bahan maupun $\mathrm{T}_{\mathrm{db}}$ hasil hantaran panas melalui termokopel type T. kelembaban Kelembaban udara (RH) di dalam dan luar dengan menggunakan Questem-34 (Gambar 2), dan kecepatan angin $\left(V_{a}\right)$ dengan menggunakan Thermohigrometer Kanomax (Gambar 3).

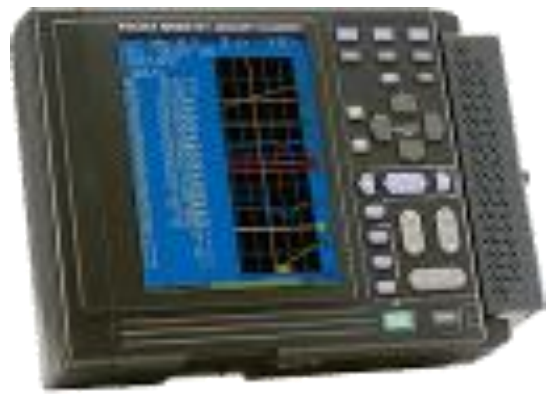

Gambar 1. Memory Logger 8422-51 dari HIOKI

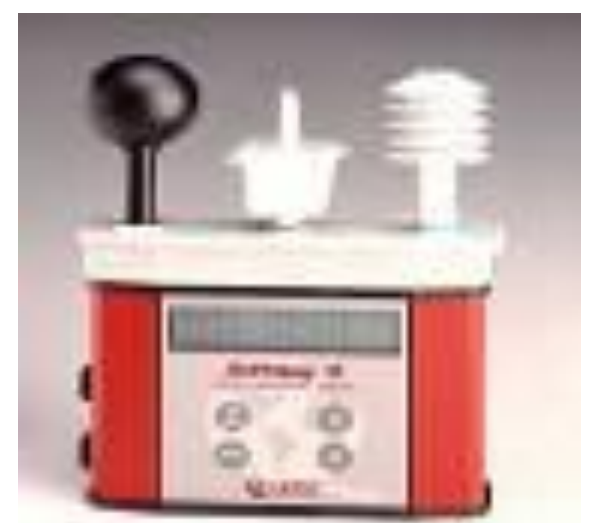

Gambar 2. Questemp-34

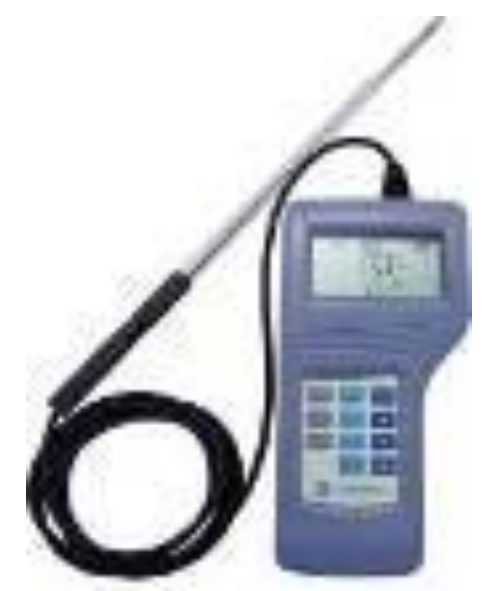

Gambar 3. Thermohigrometer Kanomax A031

Analisis data dilakukan dengan mencari rata-rata suhu, maksimum, dan minimum kemudian mendeskripsikannya dengan membandingkan suhu dalam dengan luar ruangan sehingga diperoleh pengaruh suhu tersebut. Time lag dianalisis menghitung jeda waktu suhu maksimum sisi dalam bahan kembali pada suhu yang normal.

\section{STUDI LITERATUR}

Batasan arsitektur tradisional umumnya tertuju pada bangunan etnik yang menurunkan ciri khas, yang dihasilkan oleh suatu pedoman yang ketat dan ditaati oleh kelompok etnis tertentu (Tjahjono, 1989). Dalam konteks tersebut, aspek fisik justru menempati prioritas akhir, sedangkan aspek non-fisik menempati prioritas utama, yang lebih meng-utamakan keabsahan terhadap alam nyata maupun alam yang lebih tinggi. Sejak dulu arsitektur tradisional di beberapa wilayah Indonesia mengalami perkembangan yang konsisten dan logis. Namun, kearifan lokal yang dibangun berdasarkan empati terhadap lingkungan sekitar, hanya diturunkan secara lisan dan diwariskan tidak secara tertulis, hanyanamun berdasarkan praktek langsung generasi penerusnya. Diiringi perkembangan peradaban dan teknologi, kearifan lokal tersebut mulai terkubur tanpa dokumentasi ilmiah, khususnya terkasit terkait sains bangunan yang idealnya mampu menjadi pedoman pembelajaran desain ke depannya.

Hasil penelitian yang ada terkait kenyamanan termal yang ada didapat menyebutkan bahwa suhu nyaman berada pada kisaran $22,2-27,4^{\circ} \mathrm{C} \mathrm{T}_{\mathrm{g}}$ (Karyono, T.H, 2007), di mana rentang suhu tersebut merupakan perwakilan suhu nyaman bagi pribumi Indonesia. Kajian lainnya membatasinya menjadi mengatakan bahwa suhu sejuk nyaman adalah 20,5$22,8^{\circ} \mathrm{C}$ (T.E) dengan kelembaban relatif $50 \%$; batas nyaman optimal antara $22,8-25,8^{\circ} \mathrm{C}$ (T.E) dengan 
kelembaban relatif 70-80\%; dan batas panas nyaman adalah $25,8-27,1^{\circ} \mathrm{C}$ (T.E) dengan kelembaban relatif $60 \%$ (Soegijanto, 1999). Kajian kenyamanan thermal lainnya, umumnya mengacu pada standar ASHRAE 55-2010. Namun kajian ini hanya melihat karakteristik kinerja bangunan terhadap transformasi panas, dengan membandingkan temperatur udara luar dan dalam khususnya. ASHRAE tidak dijadikan pedoman, mengingat umumnya standart tersebut digunakan di negara yang memiliki 4 (empat) musim. Karakteristik material alam juga belum terakomodasi dalam pengukuran dengan penggunaan standart ASHRAE.

Beberapa aspek terkait kenyamanan termal yang tercipta, menjadi fockus dari penelitian ini, salah satunya adalah Time Lag yang merupakan waktu tunda karena massa termal bahan. Dimana semakin tebal dan resistif suatu bahan maka semakin lama waktu yang dibutuhkan untuk merambatkan panas/ kalor. Untuk mengetahui time lag bahan selubung bangunan menggunakan pendekatan selisih antara suhu maksimum permukaan luar bahan dengan suhu maksimum permukaan dalam dengan pendekatan fungsi sinusoida seperti yang diilustrasikan pada Gambar 4.

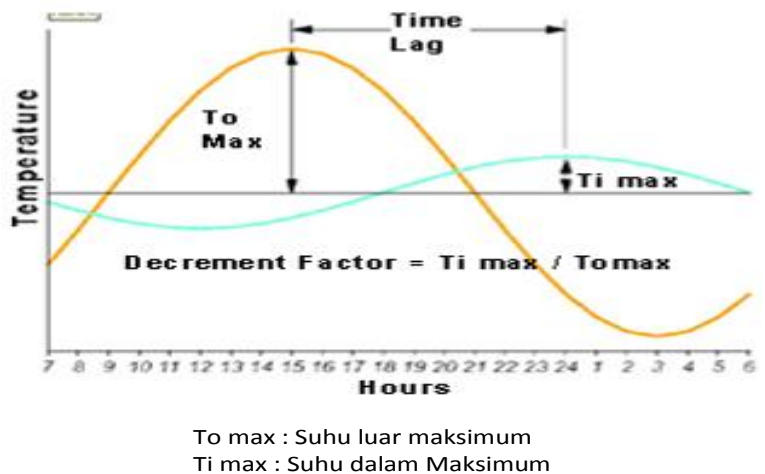

Sumber: http://learn.greenlux.org/packages/clear/thermal/buildings/building fabric/

Gambar 4. Grafik untuk Mengukur Time Lag Bahan

Suhu permukaan diukur dengan memasang termokopel tipe $\mathrm{T}$ pada permukaan bahan selubung setinggi 1,5 m dari permukaan lantai. Sensor tersebut akan mendeteksi suhu permukaaan bahan yang selanjutnya akan disimpan dalam Logger sebagai data. Pada kasus rumah tradisional Uma Lengge, hampir tidak ada bukaan pada selubungnya, hanya terdapat bukaan pintu untuk akses keluar masuk ruangan dengan luasan hanya $80 \mathrm{~cm}^{2}$ yang setiap saat tertutup seperti terlihat pada Gambar 6.

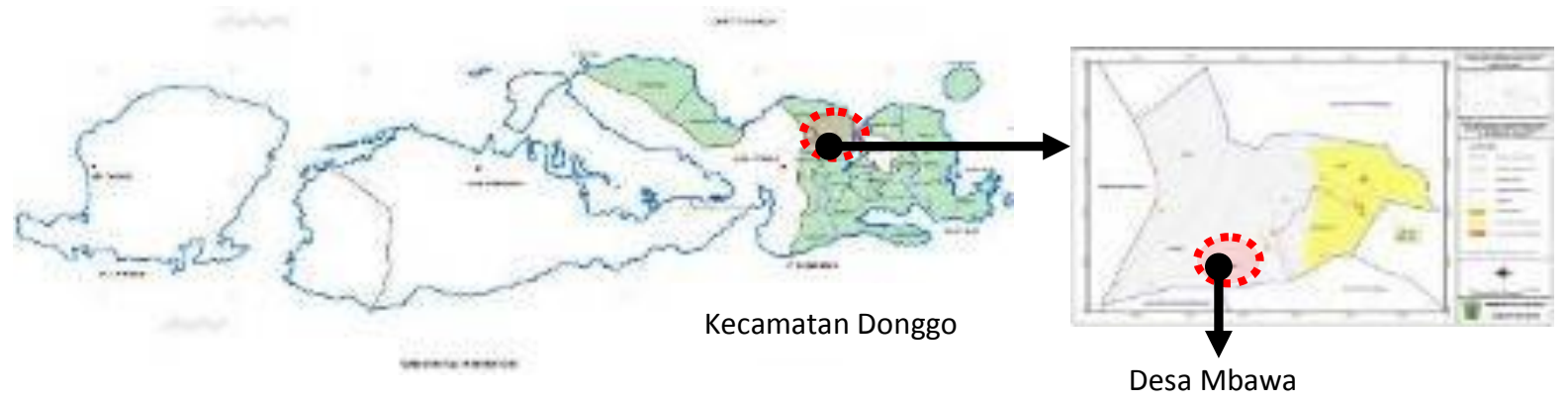

Sumber: Pemerintah Daerah Kabupaten Bima

Gambar 5. Lokasi Desa Mbawa

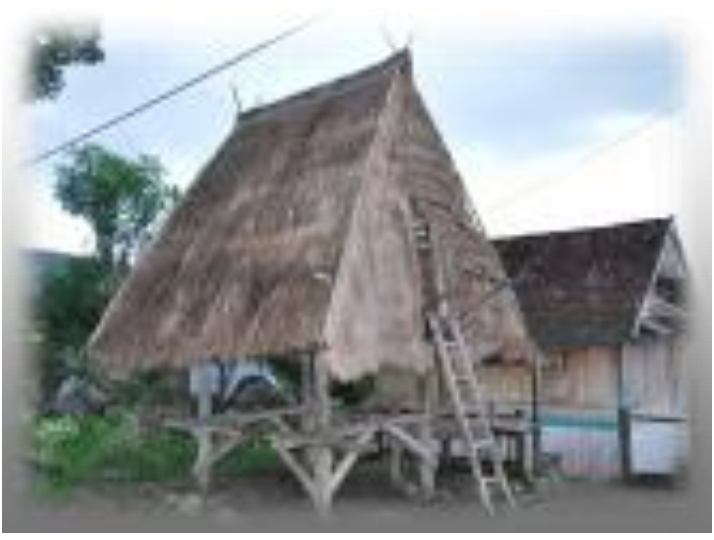

(a)

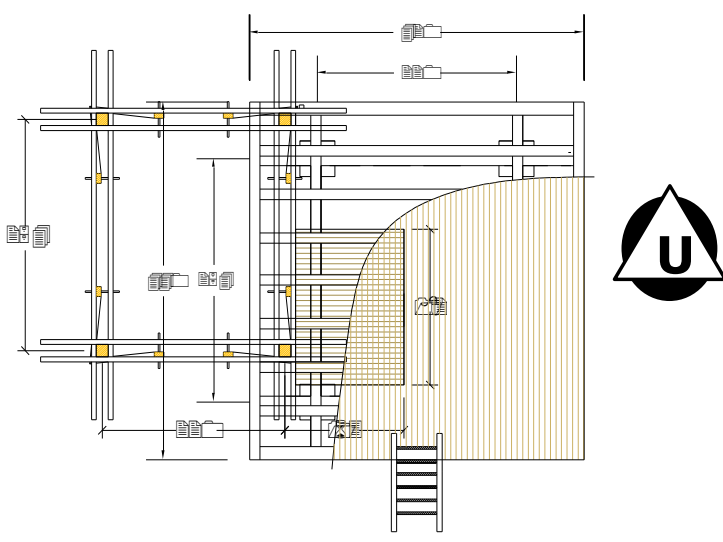

(b)

Gambar 6. Uma Lengge: a) Fasade bangunan; b) Denah Lantai 1 


\section{HASIL DAN PEMBAHASAN}

\section{Lokasi Uma Lengge}

Desa Mbawa merupakan salah satu desa tradisional yang terletak berada di Kabupaten Bima padayang terletak di jajaran perbukitan Gunung Lambitu yang merupakan gunung tertinggi di Kabupaten Bima (Gambar 5).

Letak geografis Desa Mbawa berada di ketinggian 600-700 meter dari permukaan laut mempengaruhi kondisi udara menjadi sejuk. Struktur dan konstruksi bangunan bangunan panggung berlantai 2 (dua) ini masih dipertahankan sebagaimana aslinya. Komponen atap berbentuk prisma segitiga dengan alang-alang sebagai bahan penutup atapnya, dimana fungsi atap dapat dikatakan sebagai pernaungan untuk ruang di bawahnya, dengan ketebalan yang beragam antara 10-20 cm (Gambar 6). Dimensi lantai I yaitu 4,4 x 4,2 meter, dengan luas ruangan $18,5 \mathrm{~m}^{2}$ biasanya berfungsi untuk tempat duduk, bertamu, dan kegiatan sosial lainnya. Lantai 2 (Gambar 7) dipergunakan sebagai tempat aktifitas sehari-hari penghuni rumah mulai dari memasak hingga tidur.

Ruang lantai 2 dengan volume $35 \mathrm{~m}^{3}$ tidak memiliki bukaan seperti jendela dan hanya dilengkapi sebuah pintu untuk akses keluar masuk ruang. Pintu dengan dimensi 90x80 $\mathrm{cm}$ tersebut tidak dibuka pada malam hari karena suhu udara relatif rendah hingga mencapai $23^{\circ} \mathrm{C}$. Sehingga penghawaan hanya berasal dari satu bukaan pintu dan berfungsi pada waktu pagi hingga sore hari saja.

\section{Karakteristik Termal Rumah Tradisional Uma Lengge pada Musim Hujan}

Dari hasil pengukuran didapat suhu ruangan maksimum sebesar $31,2^{\circ} \mathrm{C}$ (Pkl.09.30) dan suhu minimum sebesar $22,7^{\circ} \mathrm{C}$ (Pkl. 06.00). Suhu di luar ruangan maksimum $34,5^{\circ} \mathrm{C}(\mathrm{Pkl} .08 .30)$ dan minimum $21,8^{\circ} \mathrm{C}$ (Pkl.06.00) (Gambar 8). Suhu ruangan ratarata $25,5^{\circ} \mathrm{C}$ atau $0,1^{\circ} \mathrm{C}$ lebih tinggi dibandingkan rataratasuhu rata-rata harian suhu $\left(25,4^{\circ} \mathrm{C}\right)$. Melihat data yang ada, ditemukan bahwa suhu maksimum tidak terjadi pada pukul 12:00, dikarenakan kondisi lingkungan yang berawan dan mendung. Rentang waktu dari suhu minimum-maksimum selama 2,5 jam. Ratarata kelembaban dalam ruangan adalah 79,9\%, dengan maksimum $89 \%$ dan minimum $64 \%$. Ratarata kelembaban luar ruangan adalah $84,4 \%$, dengan maksimum 93\% dan minimum 59\% (Gambar 9).

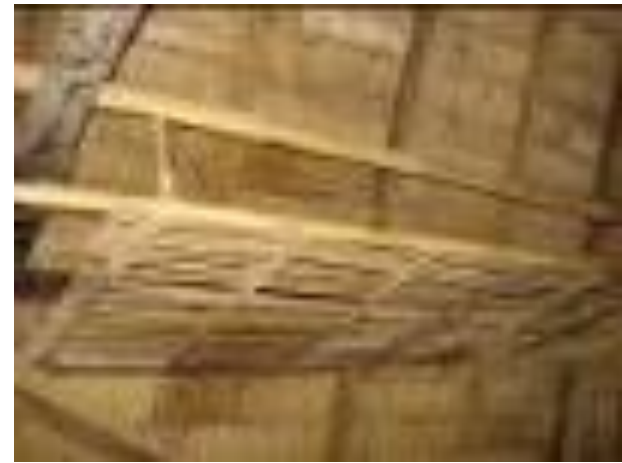

(a)

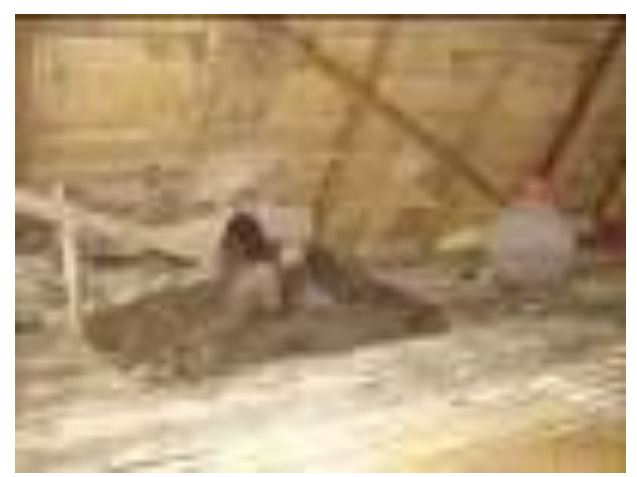

(b)

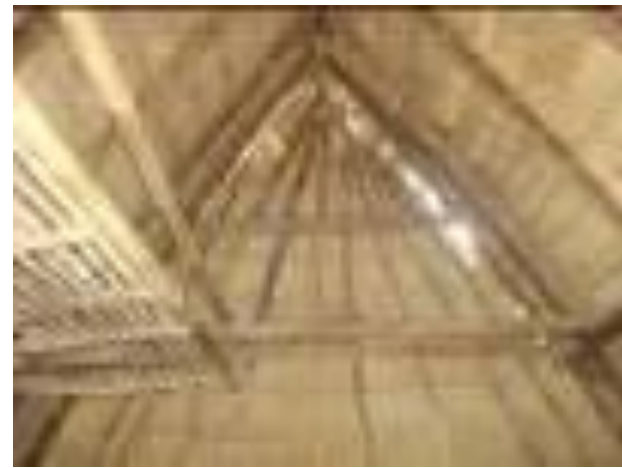

(c)

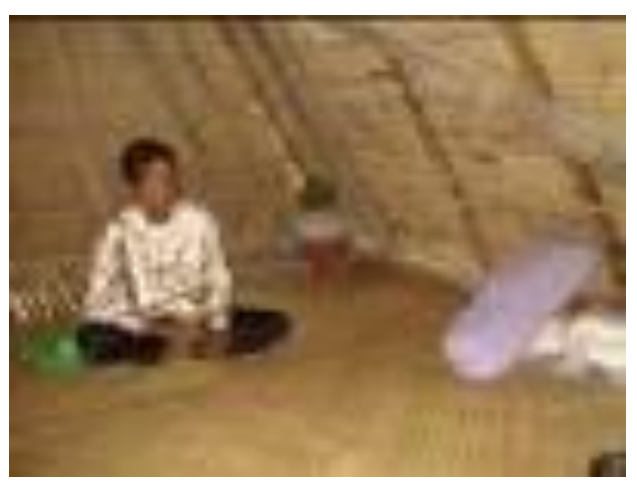

(d)

Gambar 7. Lantai II, ruang penghuni beraktivitas seharihari; (a) Rak; (b) Tungku; (c) Kondisi atap; (d) Ruang duduk 
Rata-rata kelembapan dalam lebih rendah dibandingkan kelembapan udara luar (4,5\%) Kisaran kecepatan udara angin di dalam ruangan antara 0 danhingga 0,5 $\mathrm{m} / \mathrm{s}$, sedangkan di luar ruangan antara 0 danhingga $2,5 \mathrm{~m} / \mathrm{s}$ (Gambar 910). Pada rentang pukul 16.30
WIT - 06.30 WIT suhu di dalam ruangan lebih tinggi dibandingkan suhu di luar ruangan dan lebih rendah pada rentang waktu pukul 07.00 WIT hingga 13.00 WIT.

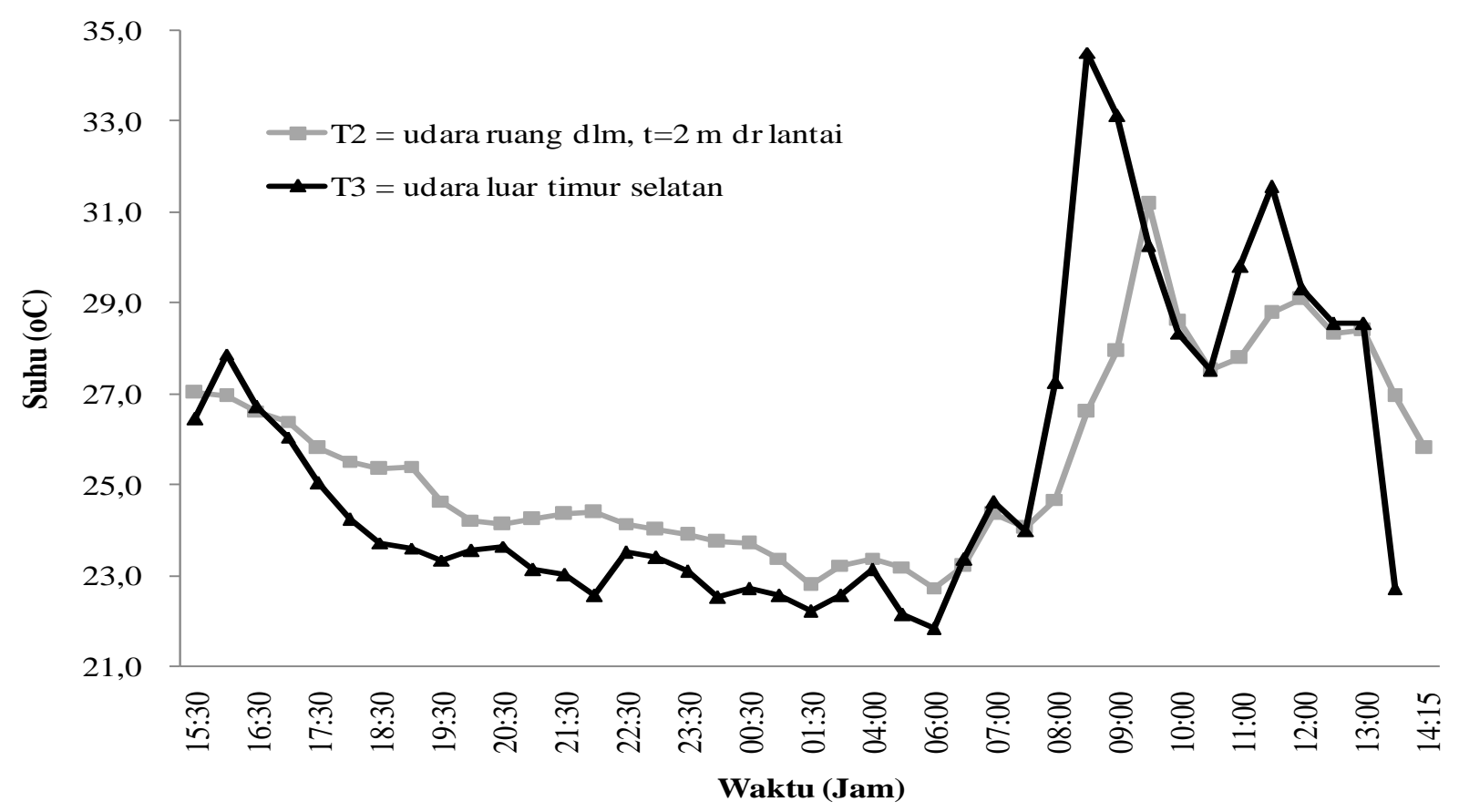

Gambar 8. Karakteristik termal dalam dan luar ruangan rumah tradisional Uma Lengge pada musim hujan

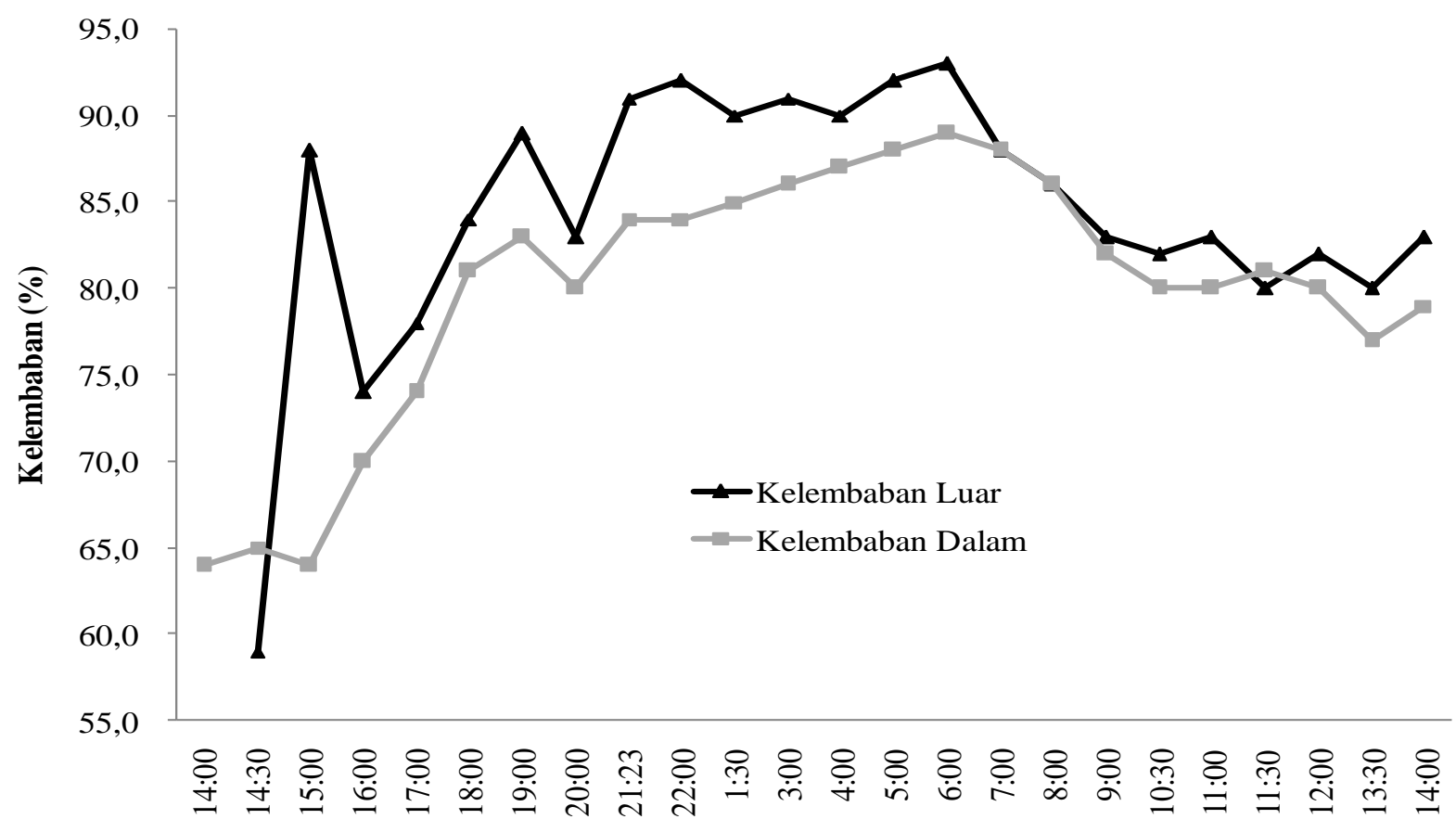

Waktu (Jam)

Gambar 9. Kelembaban dalam dan luar ruangan rumah tradisional Uma Lengge pada musim hujan 


\section{Karakteristik Termal Rumah Vernakuler Uma Lengge pada Musim Kemarau}

Gambar 11 menunjukkan suhu ruangan maksimum sebesar $25,6^{\circ} \mathrm{C}$ dicapai pada pukul 08.10 WIT dan suhu ruangan minimum sebesar $18,9^{\circ} \mathrm{C}$ yang dicapai pada pukul 20.40 WIT. Suhu di luar ruangan maksimum $28,8^{\circ} \mathrm{C}$ yang terjadi pada pukul 15.40 WIT dan minimum $18,9^{\circ} \mathrm{C}$ yang terjadi pada pukul 02.40 WIT. Suhu ruangan rata-rata $21,6^{\circ} \mathrm{C}$ atau sekitar $0,8^{\circ} \mathrm{C}$ lebih tinggi dibandingkan rata-rata suhu di luar ruangan $\left(20,8^{\circ} \mathrm{C}\right)$. Rata-rata kelembaban dalam ruangan adalah $82,6 \%$, dengan maksimum $96 \%$ dan minimum $67 \%$. Rata-rata kelembaban luar ruangan

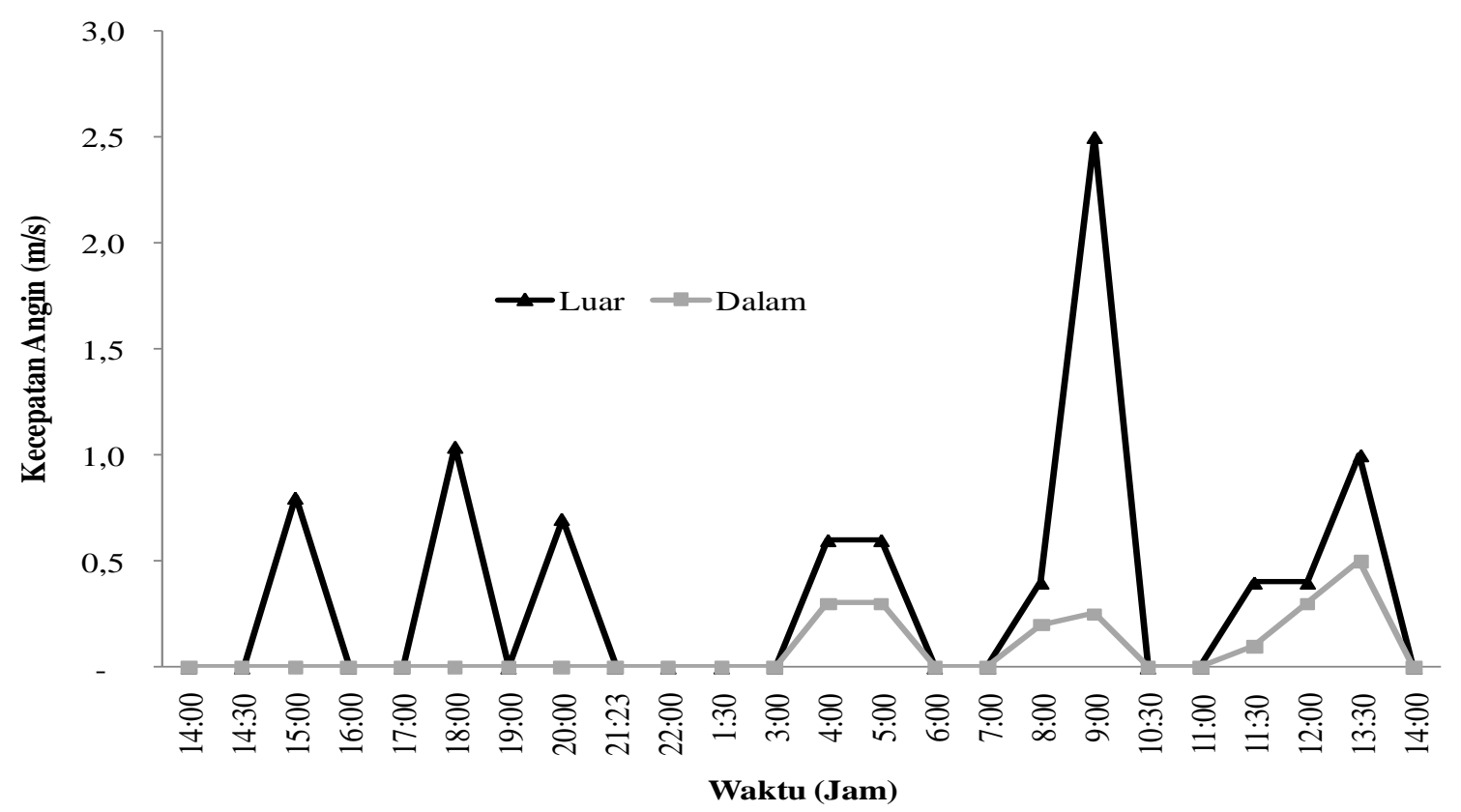

Gambar 10. Kecepatan angin dalam dan luar ruangan rumah tradisional Uma Lengge pada musim hujan

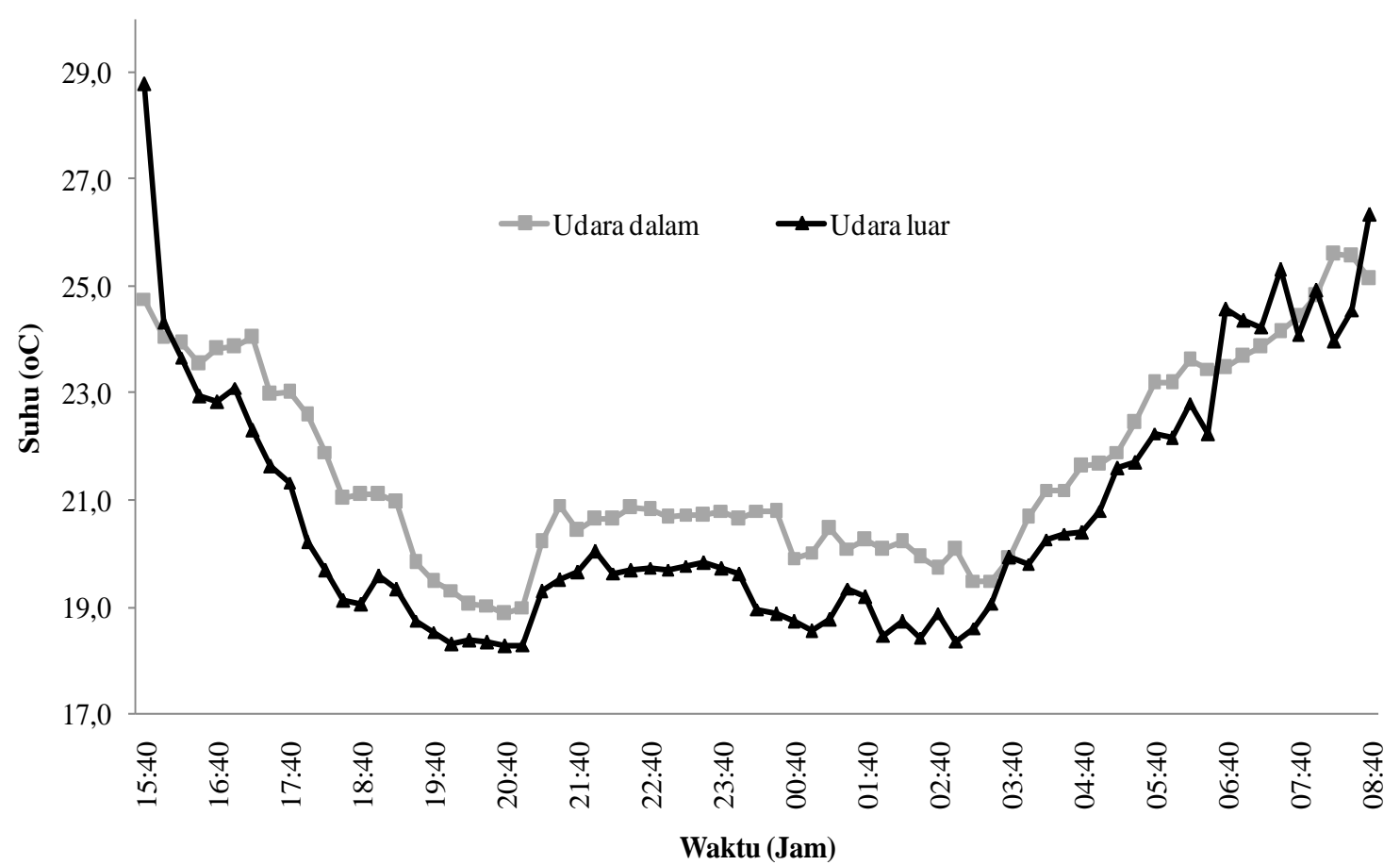

Gambar 11. Karakteristik termal dalam dan luar ruangan rumah tradisional Uma Lengge pada musim kemarau 
adalah $82,1 \%$, dengan maksimum $97 \%$ dan minimum 66\% (Gambar 1112). Kisaran kecepatan udara di dalam ruangan adalah antara 0 hingga $0,5 \mathrm{~m} / \mathrm{s}$, sedangkan kecepatan udara luar antara 0,1 hingga 2,3 $\mathrm{m} / \mathrm{s}$ (Gambar 1213). Suhu luar rata-rata cenderung lebih rendah dibandingkan suhu di dalam ruangan. Pada rentang pukul 15.40-05.50 WIT suhu dalam ruangan tetap lebih tinggi mengikuti suhu luarnya, namun radiasi matahari menyebabkan perbedaan suhu dalam ruangan dengan luar ruangan menjadi lebih besar. Jika dilihat dari rentang suhu nyaman di wilayah tropis lembab $\left(24-28^{\circ} \mathrm{C}\right)$, rumah tradisional Uma Lengge di musim kemarau berada dalam zona nyaman.

Pada Tabel 1 dijelaskan rata-rata suhu ruangan berada pada rentang suhu nyaman $\left(21,6-25,5^{\circ} \mathrm{C}\right)$ dengan kelembaban yang relatif tinggi (79,9-82,6\%). Hal ini karena ketebalan dan kondisi kering-basah dari alang-alang juga sangat mempengaruhi kadar air dalam udara, sehingga menjadi cenderung tinggi. Kecepatan udara dari luar ke dalam ruangan relatif rendah, sehingga memperlambat proses perpindahan kalor sehingga uap air tertahan dalam ruangan.

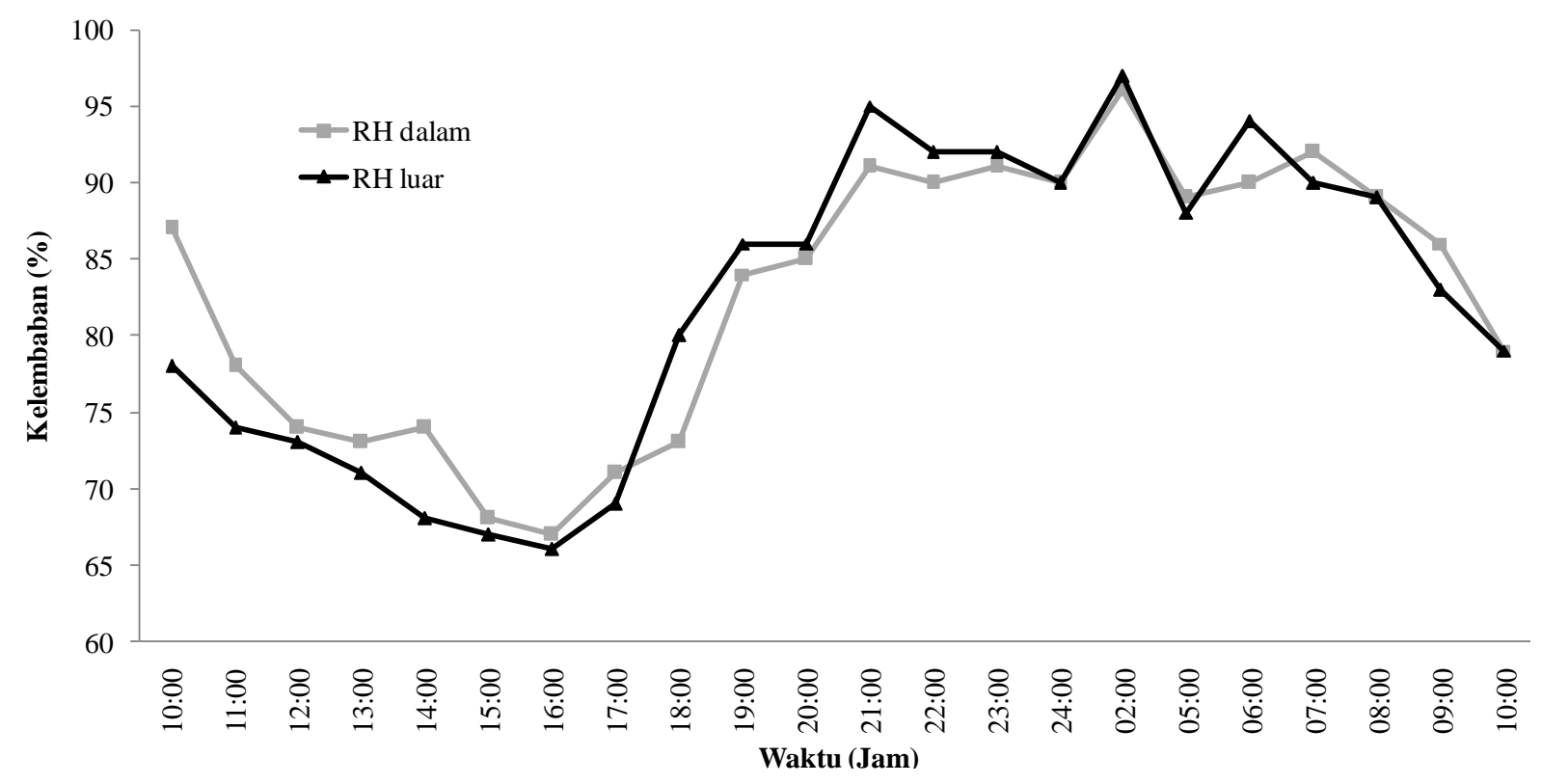

Gambar 12. Karakteriktik kelembaban dalam dan luar ruangan rumah tradisional Uma Lengge pada musim kemarau

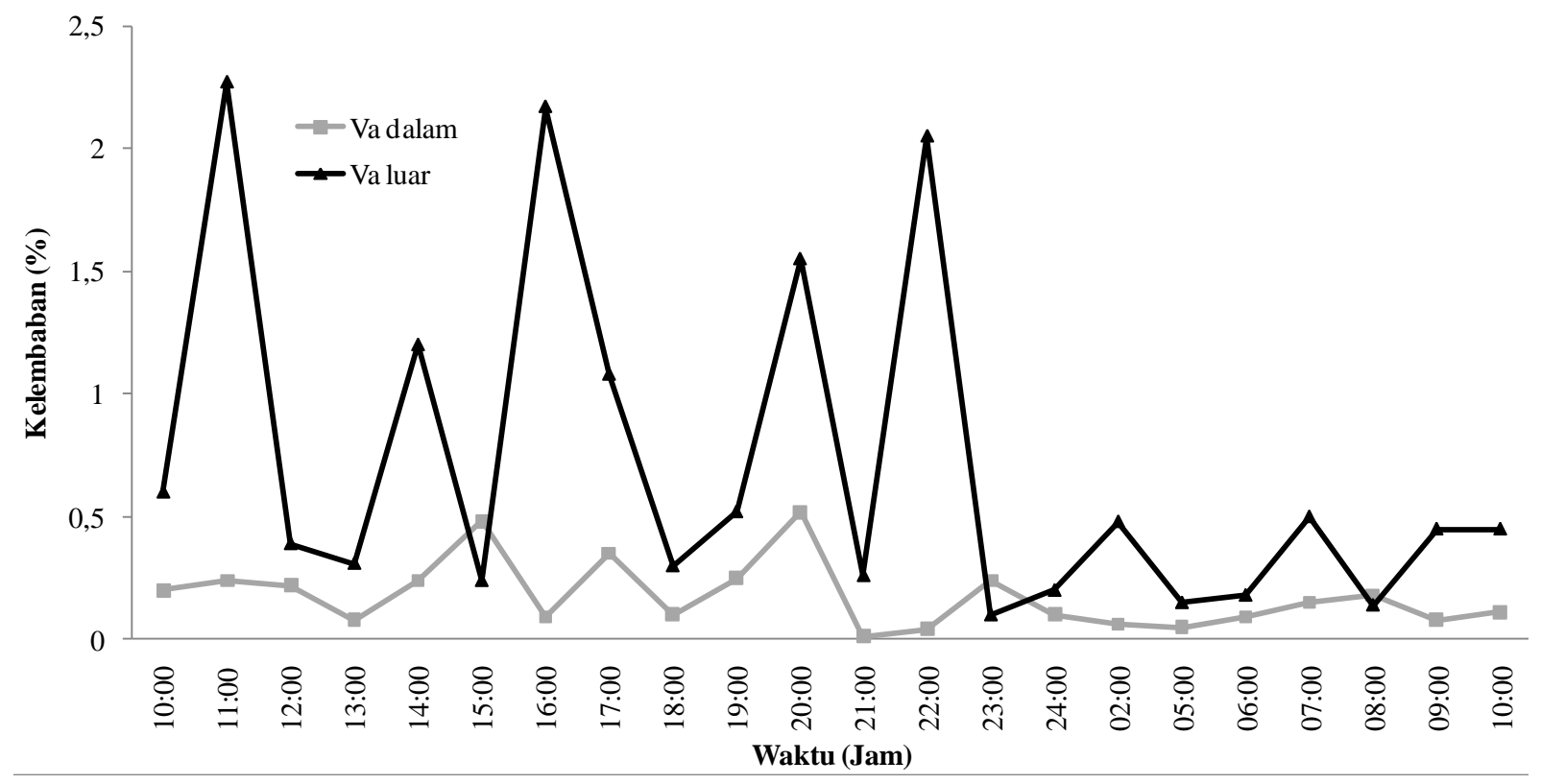

Gambar 13. Kecepatan angin dalam dan luar ruangan rumah tradisional Uma Lengge pada musim kemarau 
Tabel 1. Perbandingan parameter iklim dalam dan luar rumah tradisional Uma Lengge pada musim hujan dan kemarau

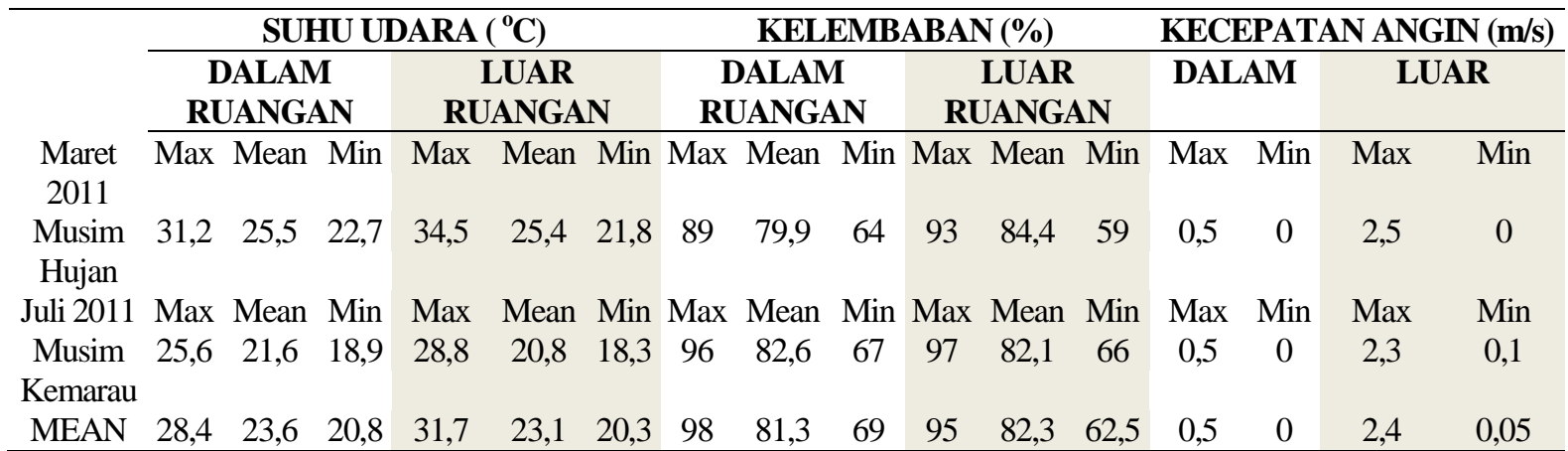

Tabel 2. Time lag bahan alang-alang pada atap dan bilah bambu pada dinding rumah tradisional Uma Lengge pada musim hujan dan kemarau

\begin{tabular}{lccccccc}
\hline \multirow{2}{*}{ Uraian } & \multicolumn{3}{c}{ Musim Hujan } & \multicolumn{3}{c}{ Musim Kemarau } \\
\cline { 2 - 7 } & Dalam & Luar & Selisih & Dalam & Luar & Selisih \\
\hline \multirow{2}{*}{ Atap timur } & Suhu Max $\left({ }^{\circ} \mathrm{C}\right)$ & 35,1 & 49,7 & 14,6 & 26,1 & 35,5 & 9,2 \\
\multirow{3}{*}{ Atap barat } & Waktu (jam) & $09: 00$ & $09: 30$ & 30 menit & $08: 10$ & $08: 40$ & 30 menit \\
& Suhu Max $\left({ }^{\circ} \mathrm{C}\right)$ & 31,1 & 31,9 & 0,8 & 25,9 & 28 & 4,3 \\
& Waktu (jam) & $12: 00$ & $11: 30$ & 30 menit & $08: 40$ & $08: 10$ & 30 menit \\
\hline
\end{tabular}

Tabel 2 menunjukkan bahwa selubung atap dari bahan alang-alang mempengaruhi suhu ruangan. Waktu yang diperlukan untuk menurunkan suhu akibat radiasi matahari dari luar ke dalam ruangan adalah di atasrata-rata 30 menit baik pada musim hujan maupun kemarau, sedangkan waktu terlamanya hingga 7 jam 30 menit. Ini menunjukkan bahwa konduktansi alang-alang dalam menghantarkan panas sangat kecil, namun besarnya konduktansi ini juga dipengaruhi oleh sifat permukaan (kekasaran dan warna), serta kecepatan angin dan temperatur permukaan. Sehingga mampu mempertahankan suhu ruangan menjadi lebih nyaman.Seperti hasil penelitian lainnya yang mengatakan bahwa pada bangunan tradisional, proses penahanan dan penangguhan panas tidak terjadi, kulit bangunan cenderung untuk adaptip terhadap kondisi diluar $\left(\mathrm{T}_{\mathrm{o}}\right)$. Sehingga pada waktu siang hari suhu udara didalam ruang $\left(\mathrm{T}_{\mathrm{i}}\right)$ panas dan malam hari dingin mengikuti fluktuasi suhu udara diluar $\left(\mathrm{T}_{\mathrm{o}}\right)$ (Santosa, 2001).

\section{KESIMPULAN}

Berdasarkan uraian pembahasan, dapat disimpulkan bahwa karakteristik termal rumah tradisional Uma Lengge dari segi termal statik adalah cukup nyaman untuk ditempati dan sangat responsif terhadap perubahan iklim. Hal ini ditunjukkan dari respon rumah yang dapat menaikkandengan adanya kenaikan suhu ruangan sebesar 0,1 -hingga $0,8^{\circ} \mathrm{C}$ pada saat kondisi suhu luar yang rendah dan menurunkan penurunan suhu ruangan sebesar 0,6-hingga $1,8^{\circ} \mathrm{C}$ pada saat kondisi suhu luar yang tinggi. Time Time lag alang-alang sebagai bahan penutup atap sebagai dinding diatas rata-rata mencapai 30 menit 30 menit hingga 7 jam 30 menit. Rentang waktu tersebut merupakan saat dimana terjadinya proses peningkatan/ penurunan suhu ruang akibat perambatan kalor dari/ke luar luar ruangan (suhu luar). yang memberi pengaruh menurunkan suhu ruangan ketika suhu luar tinggi dan menaikkan suhu ruangan ketika suhu luar rendah.

Ketika suhu di luar ruangan rendah, suhu di dalam ruangan tetap lebih tinggi daripada suhu di luar ruangan, hal ini menjaga penghuninya tetap merasa hangat dalam ruangan.

\section{Ucapan Terimakasih}

Terimakasih kami ucapkan kepada Kepala Balai Pengembangan Teknologi Perumahan Tradisional Denpasar, Pusat Penelitian dan Pengembangan Permukiman, Kementerian Pekerjaan Umum sekaligus sebagai penanggung jawab kegiatan, Iwan Suprijanto, ST, MT; Koordinator Kegiatan: Drs. Muhajirin, MT; dan Anggota Tim Kegiatan: Desak Putu Damayanti, ST, Rini Nugrahaeni, ST, M. Nur Fajri Alfata, ST, MT. 


\section{DAFTAR PUSTAKA}

Balai Pengembangan Teknologi Perumahan Tradisional Denpasar. (2011). Pengkajian Kenyamana Termal Bangunan Tradisional di Propinsi Bali, NTB dan NTT. Denpasar: Laporan Akhir, Balai PTPT Denpasar.

Santosa, Mas. (Juli 2001). Harmoni di Lingkungan Tropis Lembab: Keberhasilan Bangunan Kolonial. Dimensi Teknik Arsitektur. 29(1), pp. 34-42.

Karyono, T.H. (November 2007). Bandung Thermal Comfort Study: Assessing the Applicability of an Adaptive Model in Indonesia. Architectural Science Review, 51(1), pp. 59-64.

Rapoport, A. (1969). House, Form and Culture, London: Prentice-Hall International, Inc.

Sueca, N.P. (1997). Perubahan Pola Spasial dan Arsitektural Rumah Tradisional di Desa Adat Kesiman Denpasar. Tesis Master. Jurusan
Arsitektur Fakultas Teknik Universitas Gadjah Mada: Yogyakarta.

Sujatmiko. (2007). Studi Kenyamanan Termal Adaptif pada Hunian Berventilasi Alami di Indonesia. Tesis, Program Studi Magister Teknik Fisika. Bandung: Institut Teknologi Bandung.

Soegijanto. (Maret 1999). Bangunan di Indonesia dengan Iklim Tropis Lembab Ditinjau dari Aspek Fisika Bangunan, Fakultas Teknologi Industri Institut Teknologi Bandung.

Tjahjono, G. (1989). Cosmos, Center and Duality in Javanese Architectural Tradition:The Symbolic dimensions of house shapes in Kotagede and surroundings. Berkeley: University of California, Disertasi.

http://learn.greenlux.org/packages/clear/thermal/build ings/building_fabric/properties/time_lag.html, diunduh 6 Pebruari 2012, jam 15:00 WITA. 